\title{
Antitumor activity of leaves of Himatanthus drasticus (Mart.) Plumel-Apocynaceae (Janaguba) in the treatment of Sarcoma 180 tumor
}

\author{
Eliane Leite de Sousa ${ }^{1, *}$, Ana Ruth Sampaio Grangeiro ${ }^{1}$, Isla Vanessa Gomes Alves Bastos ${ }^{1}$, \\ Guilherme Carvalho Ribeiro Rodrigues, ${ }^{1}$ Maria Joselice e Silva ${ }^{2}$, Falba Bernadete Ramos dos \\ Anjos $^{3}$, Ivone Antonia de Souza ${ }^{1}$, Cicero Ernandes Leite de Sousa ${ }^{4}$
}

\begin{abstract}
${ }^{1}$ Department of Antibiotics, Laboratory of Pharmacology and Experimental Oncology, Federal University of Pernambuco, ${ }^{2}$ Department of Pharmaceutical Sciences, Federal University of Pernambuco, ${ }^{3}$ Department of Histology, Federal University of Pernambuco, ${ }^{4}$ Department of Biological Sciences, Regional University of Cariri.
\end{abstract}

\begin{abstract}
Himatanthus drasticus, also known as janaguba, is used popularly in Brazil's Northeastern region in the treatment of cancer. However, no scientific reports are available. The present study is the first investigation on the antitumor activity of crude methanolic extract from Himatanthus drasticus leaves against Sarcoma 180 tumor and on its side effects including acute oral toxicity. The OECD 423 methodology was used to study acute oral toxicity, and the STOCK methodology to assess antitumor activity. The crude extract showed low toxicity at the tested doses $(50,300$ and $2000 \mathrm{mg} / \mathrm{kg}$ ) administered orally. The histopathological analyses demonstrated alterations in liver lung, spleen and kidney. It also showed activity against Sarcoma 180 tumor in male Swiss albino mice, evidencing tumor growth inhibition of $67.7 \%$ and $68 \%$ at $300 \mathrm{mg} / \mathrm{kg}$ and $400 \mathrm{mg} / \mathrm{kg}$ doses, respectively.
\end{abstract}

Uniterms: Himatanthus drasticus/antitumor activity. Himatanthus drasticus/acute oral toxicity. Janaguba/ antitumor activity. Sarcoma 180/experimental study.

\begin{abstract}
Himatanthus drasticus, conhecida popularmente como janaguba, tem uma longa história de emprego na cura do câncer no nordeste brasileiro, porém quase sem registro na literatura. O objetivo desse trabalho foi investigar a atividade antitumoral do extrato bruto metanólico das folhas de Himatanthus drasticus frente ao modelo experimental Sarcoma 180 e avaliar sua toxicidade aguda. A determinação da toxicidade aguda foi realizada segundo a metodologia da OECD 423 e o transplante do tumor sólido de sarcoma 180 foi realizado seguindo a metodologia de Stock. O extrato apresentou baixa toxicidade nas doses testadas $(50,300$ e $2000 \mathrm{mg} / \mathrm{kg})$ por via oral. A análise histopatológica apresentou alterações em nível hepático, pulmonar, baço e renal. A atividade antineoplásica apresentou inibição tumoral significativa em relação ao grupo controle nas doses de $300 \mathrm{mg} / \mathrm{kg}$ e $400 \mathrm{mg} / \mathrm{kg}$ de peso do animal com um percentual de inibição de $67.7 \%$ e $68 \%$ respectivamente. Na menor dose analisada, $200 \mathrm{mg} / \mathrm{kg}$, o percentual de inibição tumoral foi apenas de $32.8 \%$.
\end{abstract}

Unitermos: Himatanthus drasticus/atividade antitumoral. Himatanthus drasticus/toxicidade aguda. Janaguba/atividade antitumoral. Sarcoma 180/estudo experimental.

\section{INTRODUCTION}

Plants contain a wide variety of compounds that have important biological activity including anticancer activity (Ramakrishna et al., 1984). Several drugs used

Correspondence: E. L. de Sousa. Departamento de Antibióticos, Universidade Federal de Pernambuco. Av. Prof. Moraes do Rêgo S/N - 50690-900 - Recife - PE, Brasil. E-mail: elianeleite10@hotmail.com to treat cancer are derived from natural products, such as Paclitaxel, a diterpenoid from Taxus brevifolia (Souza, 2004), Vinca alkaloids such as vincristine and vinblastine from Catharanthus roseus (Almeida et al., 2005), natural alkaloid camptothecin from Camptotheca acuminata (Silva et al., 2003), amongst others. Therefore, the analysis of plants is key to developing purified and well-defined chemical compounds for dose-controlled medications. 
The toxicity determination of plant extracts is relevant because there is no single beneficial effect whereas biotransformation occurs, and these products can have toxic side effects which are harmful to human health (Hilary et al., 2004).

The plant of the Himatanthus (Apocynaceae) genus is a medium-sized tree, growing on firm ground in South America from Southeastern regions of Brazil to the French Guiana (Plumel, 1991). In the Araripe National Forest, south of the State of Ceará, the species found is $H$. drasticus, known as Janaguba. Its wood stem latex is popularly used in the treatment of cancer in Brazil's Northeastern Region (Amaro et al., 2006a).

To our knowledge, only three papers have been reported in the literature on H. drasticus. However, there are no studies describing its leaves or anti-tumoral activity (Amaro et al., 2006a; Colares et al., 2008).

In 2008, Colares et al. isolated and identified an ethanolic extract from $H$. drasticus stem bark, namely, triterpene lupeol cinnamate which is probably a substance with potential for anti-tumor activity. The active ingredient of $H$. sucuuba was also isolated (an iridoid fulvoplumierin) and this also showed activity against the human epidermoid carcinoma of the nasopharynx (Perdue, Blomster, 1978).

In this study, the acute oral toxicity and antitumor activity against Sarcoma 180 tumor of the crude methanolic extract from Himatanthus drasticus leaves was described.

\section{EXPERIMENTAL}

\section{Plant material}

Leaves of Himatanthus drasticus were collected in December of 2007 at Araripe National Forest, Jardim, Ceará, Brazil, and identified by Marlene Barbosa, $\mathrm{PhD}$. A sample specimen $\left(\mathrm{n}^{\circ} 48.961\right)$ was deposited at the herbarium Geraldo Mariz of the Federal University of Pernambuco (UFPE).

\section{Extract preparation}

The leaves were dried at room temperature in fresh air for seven days, and then cut into small fragments. The sample material $(500 \mathrm{~g})$ was macerated with methanol at room temperature $\left(30 \pm 2{ }^{\circ} \mathrm{C}\right)$. Three extractions were made allowing $48 \mathrm{~h}$ for each macerated extraction. Solvent was evaporated at $60{ }^{\circ} \mathrm{C}$ under reduced pressure and dried in a high vacuum for $10 \mathrm{~h}$ affording the crude extract (100.6 g).

\section{Animals}

60 day-old male Swiss albino mice weighing between 25 and $35 \mathrm{~g}$ were housed under controlled temperature conditions $\left(22 \pm 2{ }^{\circ} \mathrm{C}\right)$ and $12 \mathrm{~h}$ light/dark cycles. Food and water were available ad libitum before and throughout the experiments. All studies were approved by the Research Ethics Committee (CEEA) of the Federal University of Pernambuco $\left(\mathrm{n}^{\circ} 23076.03566 / 2008-71\right)$ in accordance with the National Institute of Health "Guide for the Care and Use of Laboratory Animals” (NIH publication no. 86-23, 1985).

\section{Acute oral toxicity}

The acute toxicity of the methanolic extract from the leaves of Himatanthus drasticus was evaluated in mice using the up-and-down procedure (OECD, 423). Male mice, (weighing from 25-35 g, aged from 6-8 weeks) received a single initial gavage containing a $50 \mathrm{mg} / \mathrm{kg}$ dose of Himatanthus drasticus leaf methanolic extract. Three animals were used for each step. The dose level used as the starting dose was selected from one of the four fixed levels: 50,300 and $2000 \mathrm{mg}$ per $\mathrm{kg}$ of body weight. The animals were continuously observed for toxicity development during the first 4 hours of administration of each dose. Finally, the number of survivors was noted after 24 hours, and these animals were then kept alive for a further 14 days while observations were made on a daily basis. The experiment was then repeated after the end of the first trial.

\section{Histopathological studies}

Macroscopic analysis and histopathological examination of the bodies of those animals subjected to acute toxicity at higher doses were performed. The liver, kidneys, spleen and lung tissues were excised and rinsed with an ice-cold normal saline solution in order to remove blood and debris adhering to the tissues. These tissues were then fixed in a $10 \%$ formalin solution for $24 \mathrm{~h}$. The fixative was removed by washing specimens thoroughly with running tap water overnight. After dehydration through a graded series of alcohols, the tissues were cleaned in methyl-benzoate, and embedded in paraffin wax. Sections were cut $7 \mu \mathrm{m}$-thick and stained with hematoxylin and eosin (Michelany, 1980). After dehydration and cleaning, the slides were mounted and observed under light microscope for details.

\section{Antitumor activity}

The transplant of the solid tumor of Sarcoma 180 was carried out according to the methodology of Stock 
et al. (1955). The treatment was initiated 48 hours posttumor transplant. The animals were divided into groups $(\mathrm{n}=5)$ : standard group (Cyclophosphamide, CTX, 10 $\mathrm{mg} / \mathrm{kg})$, control group $(\mathrm{NaCl} 0.9 \%)$ and treated groups I, II and III, which received the methanolic extract from janaguba, at 200, 300 and $400 \mathrm{mg} / \mathrm{kg}$ doses, respectively. All substances had been managed by oral administration during the previous seven days. On the eighth day, the animals were sacrificed and their tumors removed and weighed. Subsequently, the difference between the treated groups and control group was calculated to give the index of tumor inhibition in accordance with the formula below.

$$
\mathrm{TWI} \%=\mathrm{C}-\mathrm{T} \times 100 / \mathrm{C}
$$

Where:

TWI $\%$ = Tumor weight inhibition (\%)

$\mathrm{C}=$ Mean tumor weight in control group animals

$\mathrm{T}=$ Mean tumor weight in treated group animals

\section{Statistical analysis}

The results are presented as mean \pm S.E.M. and statistical significance between the groups was analyzed by mean of variance analysis followed by Student's $t$ test. $P$ values $<0.05$ were considered significant.

\section{RESULTS AND DISCUSSION}

\section{Acute oral toxicity}

In the study for acute toxicity, the animals were treated with a single dose of the extract in question for a period of approximately $24 \mathrm{~h}$ (Simões, 2003). The oral administration of the methanolic extract from $\mathrm{H}$. drasticus leaves at doses of 50 and $300 \mathrm{mg}$ presented no alteration in the animals during the first 30 minutes of observation. The animals remained without changes after 14 days. Within the first 15 minutes of $2000 \mathrm{mg} / \mathrm{kg}$ dose administration, the animals presented excitability and agitation including exophthalmia, agitation, vibrissa, stereotyped and circle movements. They also presented increased respiratory rate, position in claw, snout edema, lack of flee attempt. After this period, depressive reactions such as lowering of the posterior train and prostration became evident. After 14 days, no mortality or changes in behavior were observed. The excitability followed by depressive behaviors suggests a reduction in the amount of stimulant neurotransmitters during the excitation phase (Fai et al., 2005). During the observation period, animals displayed no variation in their general appearance. These results obtained for methanolic extract from $H$. drasticus leaves were in accordance with the norms established for OECD 423, and presented low toxicity for oral administration at $2000 \mathrm{mg} / \mathrm{kg}$. The general results for acute oral toxicity are shown in Table I.

\section{Histopathological studies}

Animal bodies were macroscopically preserved. Histopathological examination of the livers presented hepatic congestion at sinusoids and the portal vessel, pericentre globular micro-steatosis, Kuffe cell proliferation, hepatocyte diffuse necrosis and mononuclear infiltrate. In the kidneys, the findings were glomerular atrophy, capsule thickening, renal cortico-medullary congestion, hemorrhage and mononuclear infiltrate. The pulmonary findings were alveolar interstitial thickening, intense pulmonary congestion, mononuclear infiltrate, pneumocyte-type II proliferation, pulmonary emphysema, edema and vessel thickening. In the spleen, the authors noted red pulp congestion, white pulp hyperplasia and apoptotic cells at the germinal center.

\section{Antitumor activity}

Laboratory animals represent a valuable experimental system for the understanding of the mechanism of cancer in humans. The majority of the currently accepted concepts of tumorigenesis are strongly influenced by cancer development models in mice. Mice organisms are accessible models and possess similar systems to humans (Kamb, 2005). Sarcoma 180 is an original mouse tumor and one of the most frequently used cell lineages in the research of antitumor activity (Lee et al., 2003; Magalhães et al., 2006).

The antitumor activity of the methanolic extract from $H$. drasticus leaves was tested by oral administration against the Sarcoma 180 experimental model. Figure 1 shows the mean weight of the tumors in the control group ( $\mathrm{NaCl} 0.9 \%$ Solution), standard group (cyclophosphamide, CTX, $10 \mathrm{mg} / \mathrm{kg})$, treated I $(200 \mathrm{mg} / \mathrm{kg})$, treated II $(300 \mathrm{mg} / \mathrm{kg})$ and treated III (400 mg/kg) groups. The standard group presented significant tumor growth inhibition of $70.4 \%$ in comparison to the control group. The treated groups also presented a reduction in tumor growth in relation to the control group; however, the doses of $300 \mathrm{mg} / \mathrm{kg}$ and $400 \mathrm{mg} / \mathrm{kg}$ also demonstrated marked tumor growth inhibition activity of $67.7 \%$ and $68 \%$, respectively. At the $200 \mathrm{mg} / \mathrm{kg}$ dose, tumor growth inhibition was $32.8 \%$.

The macroscopic analysis of the animals of the control group revealed hemorrhagic ascites; solid and invasive tumor, adhered to epidermis and well vascularized. 
TABLE I - Toxic effects for methanolic extract from $H$. drasticus leaves in male Swiss albino mice (Mus musculus)

\begin{tabular}{lccc}
\hline EFFECTS & \multicolumn{3}{c}{ DOSES $(\mathrm{mg} / \mathrm{kg})$} \\
STIMULANT & 50 & 300 & 2000 \\
\hline Tachycardia & - & - & - \\
Tachypnea & - & - & + \\
Piloerection & - & - & ++ \\
Agitation & - & - & + \\
Exophthalmia & - & - & + \\
Stereotyped Movements & - & - & +++ \\
Circle Movements & - & - & ++ \\
Vibrissa Movements & - & - & + \\
Tail Curl & - & - & + \\
Fine/Coarse Tremors & - & - & - \\
Position in Claw & - & - & + \\
Flee Reaction & - & - & +++ \\
DEPRESSIVE & & & \\
Lowering of the posterior member & - & - & + \\
Apnea & - & - & - \\
Alteration in gait & - & - & - \\
Sleepiness & - & - & - \\
Prostration & - & - & ++ \\
OTHERS & - & & + \\
Fecal Elimination & - & - & + \\
Diuresis & - & - & + \\
Abdominal Movements & - & - & - \\
Petechiae & - & - & + \\
Snout Edema & - & - & - \\
Cyanosis & - & - \\
Photophobia & - & - \\
Reflux & - & - \\
\hline Data obtained & - & - \\
\hline & - & - & + \\
\hline & - & & - \\
\hline
\end{tabular}

Data obtained within first 30 minutes of oral administration.

(-) No Effect; (+) Mild Effect; (++) Moderate Effect; $(+++)$ Severe Effect.

However, in the treated groups, only the Treated I group $(200 \mathrm{mg} / \mathrm{kg})$ presented ascites, solid and invasive tumor, adhered to epidermis and well vascularized. The Treated II $(300 \mathrm{mg} / \mathrm{kg})$ and Treated III $(400 \mathrm{mg} / \mathrm{kg})$ groups presented well described solid tumors which were less vascularized than control group tumors.

The mechanism underlying janaguba antitumor activity has not yet been elucidated. It is known that the Himatanthus genus has iridoid and triterpene in its chemical constitution, and one of these substances is likely responsible for the activity. Detailed studies are being carried

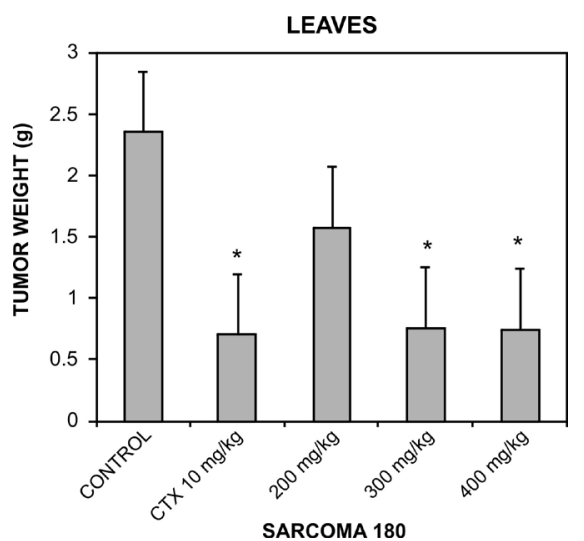

FIGURE 1 - Mean tumor weight. ${ }^{*} \mathrm{p}<0.05$ comparing treated groups with control group ( normal saline solution). Student's $t$ test ( $=5$ /group).

to clarify the antitumor activity of leaves of $\mathrm{H}$. drasticus as well as to determine new routes of drug administration.

Based on these results, we can conclude that the methanolic extract from $H$. drasticus leaves possesses low toxicity and significant antitumor activity at the tested doses administered orally. The results for antitumor activity were very good in relation to control cyclophosphamide, the synthetic drug widely used in chemotherapy protocols. The extract was also found to be safe in terms of acute toxicity in experimental animal models whereas further studies are necessary on its chronic toxicity, mutagenicity and carcinogenicity to ascertain the safety and benefits of the plant.

\section{ACKNOWLEDGEMENTS}

The authors would like to thank the Conselho Nacional de Desenvolvimento Científico e Tecnológico (CNPq-Brazil) for financial support and scholarships. Authors also extend their thanks to Dr. Marlene Barbosa for botanical identification.

\section{REFERENCES}

ALMEIDA, V. L.; LEITÃO, A.; REINA, L. C. B.; MONTANARI, C. A.; DONNICI, C. L.; LOPES, M. T. P. Câncer e agentes antineoplásicos ciclo-celular específicos e ciclo-celular não específicos que interagem com o DNA: uma introdução. Quim. Nova, v.28, n.1, p.118-129, 2005.

AMARO, M. S.; FILHO, S. M.; GUIMARÃES, R. M.; TEÓFILO, E. M. Influência da temperatura e regime de luz na germinação de sementes de Janaguba (Himatanthus drasticus) (MART.) Plumel.-Apocynaceae. Ciênc. Agrotec. Lavras, v.30, n.3, p.450-457, 2006a. 
AMARO, M. S.; FILHO, S. M.; GUIMARÃES, R. M; TEÓFILO, E. M. Morfologia de frutos, sementes e de plântulas de Janaguba Himatanthus drasticus (MART.) Plumel.-Apocynaceae. Rev. Bras. Sementes, v.28, n.1, p.63-71, 2006b.

COLARES, A. V.; CORDEIRO, L. N.; COSTA, J. G. M.; SILVEIRA, E. R.; CAMPOS, A. R.; CARDOSO, A. H. Phytochemical and biological preliminary study of Himatanthus drasticus (Mart.) Plumel (Janaguba). Pharmacog. Mag., v.4, n.14, p.73-77, 2008.

FAI, P. B. A.; FAGANDE, S. O. Acute toxicity of Euphorbia Kamerunia on Oreochrmis niloticus. Ecotoxicol. Environ. Saf., v.62, n.1, p.123-131, 2005.

HILARY, J. E.; ISRAILI, Z. H.; LYOUSSI, B. Acute and chronic toxicological studies of Ajuga ivain experimental animals. J. Ethnopharmacol., v.91, n.1, p.43-50, 2004.

LEE, Y. L.; KIM, H. J.; LEE, M. S.; KIM, J. M.; HAN, J. S.; HONG, E. K.; KWON, M. S.; LEE, M. J. Oral administration of Agaricus blazei (H1 strain) inhibited tumor growth in a sarcoma 180 inoculation model. Exp. Anim., v.52, n.5, p.371-375, 2003.

KAMB, A. What's wrong with our cancer models? Nature Rev. Drug Discov., v.4, n.2, p.161-165, 2005.

MAGALHÃES, H. I. F.; VERAS, M. L.; TORRES, M. R.; ALVES, A. P. N. N.; PESSOA, O. D. L.; SILVEIRA, E. R.; COSTA-LOTUFO, L. V.; MORAES, M. O.; PESSOA, C. In vitro and in vivo antitumor activity of physalins $\mathrm{B}$ and $\mathrm{D}$ from Physalis angulata. J. Pharm. Pharmacol., v.58, n.2, p.235-241, 2006.

MICHALANY, J. Técnica histológica em anatomia patológica. São Paulo: Editora Pedagógica e Universitária Ltda, 1980. p. 277 .
ORGANIZATION FOR ECONOMIC COOPERATION AND DEVELOPMENT. OECD. Guideline for Testing of Chemicals. Guideline 423. Acute Oral Toxicity-Acute Class Method. Adopted 17th December 2001. Available at: $<$ http://iccvam.niehs.nih.gov/SuppDocs/FedDocs/OECD/ OECD_GL423.pdf>.Accessed on: 10 dec. 2007.

PERDUE, G. P.; BLOMSTER, R. N. South American plants III: Isolation of fulvoplumierin from Himatanthus sucuuba (M. Arg.) Woodson (Apocynaceae). J. Pharm. Sci., v.67, n.9, p.1322-1323, 1978.

PLUMEL, M. M. Le genre Himatanthus(Apocinaceae). Revisión taxonomique: brandea. Bol. Herb. Bradeanu, v.5, p.1-20, 1991.

RAMAKRISHNA, Y.; MAHONOR, A. I.; MAMATA, P.; SHREEKANT, K. G. Plants and novel antitumour agents: A review. Indian Drugs, v.21, n.1, p.173-185, 1984.

SILVA, M. N.; FERREIRA, V. F.; SOUZA, M. C. B. Um panorama atual da química e da farmacologia de naftoquinonas, com ênfase na $\beta$-lapachona e derivados. Quim. Nova, v.26, n.3, p.407-416, 2003.

SIMÕES, C. M. O. Farmacognosia: da planta ao medicamento. 5.ed. Porto Alegre: UFRGS/UFCS, 2004. p.256.

SOUZA, M. V. N. Novos produtos naturais capazes de atuar na estabilização de microtúbulos, um importante alvo no combate ao câncer. Quim. Nova, v.27, n.2, p.308-312, 2004.

STOCK, C. C.; CLARCK, D. A.; PHILIPS, F. S. Sarcoma $180-$ inhibitor screening date. Cancer Res., v.15, n.2, p.2-3, 1955.

Received for publication on $22^{\text {nd }}$ January 2009 Accepted for publication on $29^{\text {th }}$ November 2009 